\title{
Effect of Lipoic Acid in a Patient with Defective Activity of Pyruvate Dehydrogenase, 2- Oxoglutarate Dehydrogenase, and Branched- Chain Keto Acid Dehydrogenase
}

\author{
I. YOSHIDA, L. SWEETMAN, S. KULOVICH, W. L. NYHAN, AND B. H. ROBINSON
}

From the Department of Pediatrics, University of California San Diego, La Jolla, California 92093 [S.K., L.S., W.L.N.); the Department of Pediatrics and Child Health, Kurume University, Kurume, Japan, [I.Y.]; and the Department of Pediatrics and Biochemistry, University of Toronto and Research Institute, The Hospital for Sick Children, Toronto, Ontario, Canada [B.H.R.]

\begin{abstract}
Lactic acidosis and accumulation of 3-hydroxybutyrate and other citric acid cycle intermediates were found in an infant with a lethal syndrome of metabolic acidosis and renal tubular acidosis. Nevertheless, the patient was relatively well for 4 mo of life. The activity of the pyruvate dehydrogenase complex, 2-oxoglutarate dehydrogenase, and branched-chain keto acid dehydrogenase were all reduced to levels 9 to $29 \%$ of control. In contrast, the activity of lipoamide dehydrogenase was normal. The conversion of $1-{ }^{14} \mathrm{C}$-leucine and $1-{ }^{14} \mathrm{C}$-valine to ${ }^{14} \mathrm{CO}_{2}$ and of $\mathrm{U}-\mathrm{L}^{-14} \mathrm{C}$-valine to its major metabolic product 3 -hydroxyisobutyric acid by fibroblasts derived from the patient was less than $5 \%$ of control. Cultivation of the patient's fibroblasts in medium enriched with lipoic acid markedly improved these in vitro conversions of leucine and valine. (Pediatr Res 27: 75-79, 1990)
\end{abstract}

\section{Abbreviations}

PDHC, pyruvate dehydrogenase complex

$\mathbf{E}_{1}$, pyruvate decarboxylase

$\mathrm{E}_{2}$, dihydrolipoyl transacetylase

$E_{3}$, lipoamide dehydrogenase

Lactic acidemia is encountered in a variety of clinical situations and a number of inborn errors of metabolism including defects in the PDHC (1). The associated accumulation of 2ketoglutarate suggests defective activity in 2-ketoglutarate dehydrogenase as well (2). The PDHC consists fundamentally of three components that act sequentially to catalyze the oxidative decarboxylation of pyruvate. They are $E_{1}, E_{2}$, and $E_{3}$. The $E_{3}$ enzyme also serves the same function in the 2-oxoglutarate dehydrogenase and in the third enzyme complex involved in oxidative decarboxylation, branched-chain keto acid dehydrogenase.

Defective activity of all three enzyme complexes suggests the presence of a defect in $E_{3}$, and a small number of patients with $\mathrm{E}_{3}$ deficiency has been reported (3-6). We describe a patient in

Received June 17, 1988; accepted August 15, 1989.

Correspondence and reprints Dr. William L. Nyhan, Department of Pediatrics, M-009A, University of California San Diego, La Jolla, CA 92093-0609.

Supported by United States Public Health Service Grant HD04608 from the National Institute of Child Health and Human Development, and General Clinica Research Center Grant RR-00827 from the Division of Research Resources, National Institutes of Health, Bethesda, MD, and NF1-377 from the March of Dimes Birth Defects Foundation, White Plains, NY. whom defective activity of these three enzyme complexes was associated with normal activity of $E_{3}$.

\section{CASE REPORT}

E.B. was admitted to the University of California San Diego Medical Center at 8 mo of age for evaluation of lactic acidosis. He had not developed acute symptomatic acidosis until 2 wk before admission, although he had appeared weak, sucked poorly, and gained weight slowly from birth. He was born in Venezuela, weighing $2250 \mathrm{~g}$, of a 22 -y-old mother and a 32-y-old father. The parents were first cousins. At $4 \mathrm{mo}$ of age he began to vomit. He gained no weight during the 6 th mo. During the next month he was brought to the United States and admitted to a children's hospital where he was found to have a low serum bicarbonate and large amounts of lactic acid in the urine. He was treated with $12 \mathrm{mEq} / \mathrm{kg} \mathrm{NaHCO}$ and transferred to San Diego (Table 1).

Physical examination on admission revealed an alert but relatively inactive male infant who did not appear acutely ill. The pulse was 132 and the respirations $28 / \mathrm{min}$, and the blood pressure was $80 / 40$. The weight was $5250 \mathrm{~g}$ (50th percentile for 2 $\mathrm{mo}$ ). The height was $64 \mathrm{~cm}$ (50th percentile for $4 \mathrm{mo}$ ), and the head circumference $18 \mathrm{~cm}$ (2nd percentile). The anterior fontanel was $4 \times 4 \mathrm{~cm}$. He was markedly hypotonic and unable to raise his head or to sit upright without support. The liver was palpable $2 \mathrm{~cm}$ below the right costal margin.

The serum concentration of bicarbonate was $14 \mathrm{mEq} / \mathrm{L}$. The sodium was 144 , potassium 4.0 , and chloride $107 \mathrm{mEq} / \mathrm{L}$. The $\mathrm{Hb}$ was $8.3 \mathrm{~g} / \mathrm{dL}$ and the hematocrit 24 . The leukocyte count was $4600 / \mathrm{mm}^{3}$ with $16 \%$ polymorphonuclear-segmented cells, and $6 \%$ band forms, $73 \%$ lymphocytes, and $5 \%$ monocytes. The blood concentration of lactate was $75 \mathrm{mg} / \mathrm{dL}$ (normal range 3 to $12 \mathrm{mg} / \mathrm{dL}$ ), and the pyruvate $3.0 \mathrm{mg} / \mathrm{dL}$ (normal range 0.3 to $0.7 \mathrm{mg} / \mathrm{dL}$ ). Repeat values over $24 \mathrm{~h}$ were 65 and 75 , and 3.2 and $3.0 \mathrm{mg} / \mathrm{dL}$. Withdrawal of supplemental $\mathrm{NaCHO}_{3}$ was followed by a decrease of the serum concentration of bicarbonate to $5 \mathrm{mEq} / \mathrm{L}$. Analysis of the amino acid concentrations of the plasma revealed an elevated alanine ranging from 6.1 to $8.9 \mathrm{mg} /$ $\mathrm{dL}$ (normal $2.7 \mathrm{mg} / \mathrm{dL}$ ). The concentrations of isoleucine, leucine and valine were $1.8,2.8$, and $3.8 \mathrm{mg} / \mathrm{dL}$, respectively, all normal values, and no alloisoleucine was detected. The excretion of the keto acid derivatives of these amino acids in the urine was elevated, but to levels much lower than in maple syrup urine disease. The excretion of 2-keto-3-methylvaleric acid was 1.9 and a combined peak of 2-ketoisocaproic acid and 2-ketoisovaleric acid was $1.2 \mu \mathrm{Eq} / \mathrm{mg}$ creatinine. The excretion of 3-hydroxyiso- 
valeric acid was $8.6 \mu \mathrm{Eq} / \mathrm{mg}$ creatinine, but this was interpreted as secondary to ketosis. Analysis of the amino acids of the urine revealed a generalized aminoaciduria. Further evidence of proximal renal tubular acidosis was a persistent urinary $\mathrm{pH}$ approximating 8.5 and $1-3+$ glycosuria. Proteinuria of $1-3+$ was also present. On admission his urine tested strongly positive for ketones. Analysis of the organic acids of the urine revealed large amounts of lactate $(391 \mu \mathrm{Eq} / \mathrm{mg}$ creatinine), acetoacetate, and 3 -hydroxyburate (Table 2). In addition the excretion of 2-oxoglutarate, fumarate, malate, and citrate were elevated. Cytogenic analysis including prometaphase studies revealed a normal 46 $X Y$ karyotype. EEG revealed focal dysrhythmia in the left temporal region. CT scan revealed evidence of cerebral atrophy.

Treatment was initiated with supplemental $\mathrm{NaHCO}_{3}$ but the condition worsened progressively and his bicarbonate requirement increased. Ultimately, it proved to be impossible to raise his serum concentration of bicarbonate without parenteral bicarbonate. Urinary obligatory water losses were such that he re-

Table 1. Chronology of clinical presentation

\begin{tabular}{|c|c|c|c|}
\hline $\begin{array}{l}\text { Age } \\
(\mathrm{mo})\end{array}$ & $\begin{array}{l}\text { Hospital } \\
\text { Day }\end{array}$ & Manifestations & Therapy \\
\hline 4 & & Vomiting & \\
\hline 6 & & Failure to thrive & \\
\hline 7 & & Acidosis, lactic acidemia & $\mathrm{NaHCO}_{3}$ \\
\hline \multirow[t]{2}{*}{8} & 1 & $\begin{array}{l}\text { Wt } 5250 \mathrm{~g} \text {; serum bicar- } \\
\text { bonate } 14 \mathrm{mEq} / \mathrm{L} \text {; } \\
\text { lactic acidemia; hyper- } \\
\text { alaninemia renal tu- } \\
\text { bular acidosis }\end{array}$ & $\mathrm{NaHCO}_{3}$ \\
\hline & $7-20$ & $\begin{array}{l}\text { Wt } 5250 \mathrm{~g} \text {; stable dur- } \\
\text { ing dietary manipula- } \\
\text { tion }\end{array}$ & $\mathrm{NaHCO}_{3}$ \\
\hline \multirow[t]{2}{*}{9} & 21 & $\begin{array}{l}\text { Lipid challenge; ketonu- } \\
\text { ria; serum bicarbon- } \\
\text { ate } 6 \mathrm{mEq} / \mathrm{L}\end{array}$ & $\begin{array}{l}0.6 \mathrm{~g} / \mathrm{kg} \text { protein, } \\
\text { plus polycose } \\
\mathrm{NaHCO}_{3} \text { and } \\
\mathrm{H}_{2} \mathrm{O}\end{array}$ \\
\hline & 49 & Stable wt $6100 \mathrm{~g}$ & $\begin{array}{l}\text { Lipoic acid } 100 \\
\text { mg q.d. } \\
\mathrm{NaHCO}_{3}\end{array}$ \\
\hline 10 & 61 & & $\begin{array}{l}\text { Lipoic acid } 200 \\
\text { mg q.d. } \\
\mathrm{NaHCO}_{3}\end{array}$ \\
\hline 11 & 82 & $\begin{array}{l}\text { Serum bicarbonate } \\
21 \mathrm{mEq} / \mathrm{L}\end{array}$ & $\begin{array}{l}\text { Lipoic acid } 300 \\
\text { mg q.d. }\end{array}$ \\
\hline 12 & $90-120$ & $\begin{array}{l}\text { Increasing bicarbonate } \\
\text { and water require- } \\
\text { ments }\end{array}$ & $\begin{array}{l}\text { IV supplementa- } \\
\text { tion }\end{array}$ \\
\hline 15 & 200 & Diarrhea-ascites-death & \\
\hline
\end{tabular}

quired 200 to $300 \mathrm{~mL} / \mathrm{kg} /$ day and $60 \mathrm{mEq} / \mathrm{kg} \mathrm{NaHCO}$ were required to achieve a normal serum level of bicarbonate. These requirements were largely met with a central jugular intravenous line. A lipid challenge was instituted with $5.5 \mathrm{~g} / \mathrm{kg} /$ day. $\mathrm{He}$ developed ketonuria, Kussmaul breathing, and vomiting. The bicarbonate, which had been brought to $12 \mathrm{mEq} / \mathrm{L}$ before challenge, fell to $6 \mathrm{mEq} / \mathrm{L}$. He was judged lipid intolerant. The lipid was removed and he was given extra $\mathrm{NaHCO}_{3}$ and water and he returned to baseline.

Lipoic acid was originally given in a dose of $200 \mathrm{mg}$ q.i.d. p.o. as reported by Matalon et al. (7). The patient developed a massive diuresis, the urine $\mathrm{pH}$ decreased to 5 and the serum bicarbonate dropped from 13 to 4 , at which time he had Kussmaul breathing and appeared ill. In addition, the serum glucose rose to $319 \mathrm{mg} /$ $\mathrm{dL}$ and there was considerable glycosuria. The lipoic acid was stopped and the blood sugar fell to $23 \mathrm{mg} / \mathrm{dL}$. The hypoglycemia and ketosis were reversed by the parenteral administration of glucose and water.

Lipoic acid was next started in a dose of $25 \mathrm{mg} 4 \mathrm{~h}$, along with thiamine $5 \mathrm{mg}$ q.d. It was well tolerated and gradually increased to $50 \mathrm{mg} \mathrm{q} 6 \mathrm{~h}$, and $75 \mathrm{mg} \mathrm{q} 6 \mathrm{~h}$. His tolerance for protein and lipid appeared to increase as evidenced by a cessation of ketonuria. The amounts of lactate and 3-hydroxybutyrate decreased in the urine despite a progressive increase in protein intake (Table 2). Concentrations of lactate and pyruvate in the blood ranged from $128-140 \mathrm{mg} / \mathrm{dL}$, respectively, in the week before initiation of lipoic acid, and $84-85$ and $2.6-4.4 \mathrm{mg} / \mathrm{dL}$ in the following weeks. The lactate was as low as $44 \mathrm{mg} / \mathrm{dL}$ whereas he was receiving $75 \mathrm{mg}$ of lipoic acid per dose and most values ranged from 66 to $86 \mathrm{mg} / \mathrm{dL}$, although the level rose as high as $133 \mathrm{mg} /$ $\mathrm{dL}$ in a day which he was otherwise stable.

Anorexia was such that nutritional needs were met by nasogastric feedings. Despite careful manipulation of dietary components it was difficult to provide sufficient protein and calories to permit adequate growth without ketonuria and increasing acidosis or diarrhea. He had frequent intercurrent infections in which he became catabolic and had increased ketonuria and acidosis; it was difficult to keep him out of the intensive care unit. He had one cardiopulmonary arrest 2 mo after admission from which he was successfully resuscitated. Recurrent anemia required a number of blood transfusions. Approximately $1 \mathrm{wk}$ before his death 7 mo after admission he developed diarrhea. He subsequently became edematous and had ascites and massive pulmonary edema. Despite intubation and ventilation, oxygenation continued to fall and he died. Postmortem examination could not be carried out.

\section{MATERIALS AND METHODS}

Quantitative analysis of the organic acids of the urine was done by liquid partition chromatography on silicic acid columns,

Table 2. Urinary organic acids

\begin{tabular}{|c|c|c|c|c|c|c|}
\hline Regimen & Lactate & 3-Hydroxybutyrate & 2-Oxoglutarate & Fumarate & Malate & Citrate \\
\hline & \multicolumn{6}{|c|}{$\mu E q / m g$ creatinine } \\
\hline Admission & 391.0 & 208.9 & 9.4 & 4.7 & 5.5 & 60.4 \\
\hline Parenteral fluid & 6.6 & 0 & 4.3 & 0 & 1.6 & 28.5 \\
\hline Protein $(0.6 \mathrm{~g} / \mathrm{kg}$ and $\mathrm{CHO})$ & 344 & 25.0 & 33.8 & 10.7 & 15.0 & 60.2 \\
\hline Lipid challenge & & 34.2 & 18.2 & 7.1 & 8.8 & 32.7 \\
\hline $\begin{array}{l}\text { Prelipoic acid ( } 75 \mathrm{gCHO}, 0.5 \mathrm{~g} / \mathrm{kg} \\
\text { protein) }\end{array}$ & 755 & 76.2 & & 1.3 & 3.1 & 41.1 \\
\hline $\begin{array}{l}\text { Lipoic }(25 \mathrm{mg} \mathrm{q} 4 \mathrm{~h} ; 0.5 \mathrm{~g} / \mathrm{kg} \\
\text { protein) }\end{array}$ & 691 & 30.9 & & 1.4 & & 25.1 \\
\hline $\begin{array}{l}\text { Lipoic }(25 \mathrm{mg} \mathrm{q} 4 \mathrm{~h} ; 0.75 \mathrm{~g} / \mathrm{kg} \\
\text { protein) }\end{array}$ & 511 & & 1.0 & 1.7 & & 33.7 \\
\hline $\begin{array}{l}\text { Lipoic }(50 \mathrm{mg} \mathrm{q} 4 \mathrm{~h} ; 1.0 \mathrm{~g} / \mathrm{kg} \\
\text { protein) }\end{array}$ & 401 & 10.0 & 24.3 & 12.6 & 22.5 & 125.2 \\
\hline Control subject & 0.2 & 0.3 & 2.7 & 0.1 & 0.1 & 20.4 \\
\hline
\end{tabular}


gas chromatography, and gas chromatography-mass spectrometry (8). The concentrations of amino acids in plasma and urine were determined on an automatic amino acid analyzer (9).

Materials and methods for the study of the metabolism of 1${ }^{14} \mathrm{C}$-L-leucine, UL- ${ }^{14} \mathrm{C}$-leucine, $1{ }^{14} \mathrm{C}$-valine, and UL- ${ }^{14} \mathrm{C}$-valine in vitro have previously been described (10). Cultured fibroblasts were derived from biopsied skin and maintained in Eagle's minimal essential medium with 10 or $15 \%$ added FCS and antibiotics. The standard incubation contained $2 \times 10^{6}$ cells in Krebs-Ringer bicarbonate buffer containing $1 \mathrm{mg} / \mathrm{mL}$ bovine serum albumin, $5.55 \mathrm{mmol} / \mathrm{L}$ glucose, $5 \mathrm{mmol} / \mathrm{L}$ thiamine, and $1 \mathrm{mmol} / \mathrm{L}^{14} \mathrm{C}$-leucine or valine $(4 \mathrm{mCi} / \mathrm{mmol})$, in a total volume of $300 \mu \mathrm{L}$. The solutions were incubated for 90 minutes at $35^{\circ}$ C. After the incubation the reaction was stopped by placing on ice; unlabeled standard organic acids were added, and the $\mathrm{pH}$ of the solutions was adjusted to $\mathrm{pH} 12$ or more with $50 \mu \mathrm{L}$ of 10 $\mathrm{mol} / \mathrm{L} \mathrm{KOH}$. Oximes of the $\alpha$-ketoacids were formed by adding $10 \mu \mathrm{L}$ of $3.6 \mathrm{~mol} / \mathrm{L}$ hydroxylamine. After acidification, the organic acids were separated by liquid partition chromatography (10). Each fraction was dried under a stream of nitrogen and counted in the Beckman LS-250 Scintillation Spectrophotometer (Beckman Instruments Inc., Fullerton, CA).

The effects of lipoic acid on metabolism of branched-chain amino acid in fibroblasts were studied in fibroblasts grown in roller bottles in minimal essential medium with $10 \%$ FCS supplemented with $10 \mathrm{mg} / \mathrm{L}$ lipoic acid. The fibroblasts were harvested with trypsin-EDTA washed three times with isotonic Krebs-Ringer phosphate buffer $\mathrm{pH} 7.4$ collected by centrifugation and resuspended at a concentration of $2 \times 10^{6}$ cells in 300 $\mu \mathrm{L}$ of Krebs-Ringer phosphate $\mathrm{pH} 7.4$ or Krebs-Ringer bicarbonate buffer $\mathrm{pH}$ 7.4. The oxidation of $1{ }^{14} \mathrm{C}$-L-leucine and $1-{ }^{14} \mathrm{C}-\mathrm{L}-$ valine and the metabolic conversions of $\mathrm{UL}-{ }^{14} \mathrm{C}-\mathrm{L}-$ leucine and $\mathrm{UL}-{ }^{14} \mathrm{C}$-valine were studied as previously described (10). The activity of PDHC and its components, $E_{1}, E_{2}$, and $E_{3}, 2$-oxoglutarate dehydrogenase and 2-ketoisocaproate dehydrogenase, were measured as previously described $(4,11)$. The activities of pyruvate carboxylase and phosphoenolpyruvate carboxykinase were assayed as control enzymes.

\section{RESULTS}

In an approach to the assessment of tolerance for the various dietary components he was initially given a mixture of Similac and carbohydrate-free formula, high in fat and low in carbohydrate, that had been useful in patients with defects in PDHC, but he developed intense ketonuria, although the blood lactate decreased to $54 \mathrm{mg} / \mathrm{dL}$ and his serum bicarbonate decreased to $7 \mu \mathrm{Eq} / \mathrm{L}$. He developed an intercurrent diarrhea and the lactate rose to $129 \mathrm{mg} / \mathrm{dL}$ (pyruvate 4.8 ). In response to the withdrawal of oral intake and the administration of parenteral fluids, the ketonuria disappeared, as did 3-hydroxybutyrate, and the other organic acids reached minimal levels (Table 1). He was then given a protein modular formula with added polycose in which the protein intake was begun at $0.5 \mathrm{~g} / \mathrm{kg}$ and gradually raised to $0.9 \mathrm{~g} / \mathrm{kg}$ and caloric intake was $85 \mathrm{cal} / \mathrm{kg}$. With this regimen he had little or no ketones in the urine, but the blood lactate gradually rose from 51 to $131 \mathrm{mg} / \mathrm{dL}$; the pyruvate was $4.6 \mathrm{mg} /$ $\mathrm{dL}$ and the serum bicarbonate fell to $8 \mathrm{mEq} / \mathrm{L}$. Urinary lactate was also massive. Levels of 2-ketoglutarate, fumarate, malate, and citrate also rose.

Enzyme activities in fibroblasts. The activity of PDHC and its components is shown in Table 3, along with data for 2-oxoglutarate dehydrogenase, pyruvate carboxylase, and phosphoenolpyruvate carboxylase. The overall activity of PDHC was reduced to $24 \%$ of control. The activity of $E_{1}$ was $33 \%$ of control and that of 2-oxoglutarate dehydrogenase was $29 \%$ of control. The activity of 2-isocaproate dehydrogenase was $9 \%$ of control. In contrast the activity of $E_{2}$ was judged to be normal at $70 \%$ of control. Similarly the activity of $E_{3}$, which was $63 \%$, appeared to be normal. The activity of control enzyme phosphoenolpyruvate carboxykinase in the patient was $60 \%$ of normal.

The rates of oxidation of $1-{ }^{14} \mathrm{C}$-L-leucine and $1-{ }^{14} \mathrm{C}$-L-valine to ${ }^{14} \mathrm{CO}_{2}$ are shown in Table 3 . The values in the patient were 6 and $4 \%$ of the control mean. In comparison the cells of a patient with classic maple syrup urine disease carried out these oxidations at 3 and $1 \%$ of control.

Effects of lipoic acid in vitro. The pattern of catabolic products of valine and the effects of supplementation of the culture medium with lipoic acid were studied chromatographically (10). In normal fibroblasts the major product of valine is 3-hydroxyisobuytric acid. In E.B. this peak was very small, and similar to those observed in patients with classic or intermittent maple syrup urine disease (10). The level of $2 \%$ of control was consistent with the results observed in the conversions of ${ }^{14} \mathrm{CO}_{2}$ (Table 4). When the fibroblasts of E.B. were incubated with valine in the presence of lipoic acid, a substantial peak of isotope was observed in 3-hydroxyisobuytric acid. The value was $56 \%$ of the control level (Table 5). Similarly the addition of lipoic acid to the culture medium improved the oxidation of leucine and valine to 45 and $25 \%$ of control, respectively (Table 5). In contrast the oxidation

\begin{tabular}{ccc} 
Table 4. Oxidation of $1-{ }^{14} \mathrm{C}$-leucine and $1-{ }^{14} \mathrm{C}$-valine to ${ }^{14} \mathrm{CO}_{2}{ }^{*}$ \\
\hline & \multicolumn{1}{c}{$\mathrm{C}$ C-Leucine } & ${ }^{14} \mathrm{C}$-Valine \\
\hline E.B. & $142 \pm 88(2)$ & $142(1)$ \\
GM612 & $71 \pm 18(2)$ & $36 \pm 18(3)$ \\
Controls (4) & $2424 \pm 426(20)$ & $3250 \pm 328(16)$ \\
\hline
\end{tabular}

* The values represent the means $\pm \mathrm{SD}$. The numbers in parentheses after the SD represent the numbers of experimental determinations. There were four control cell lines. GM612 was a cell line derived from a patient with maple syrup urine disease.

Table 3. Activities of enzymes in fibroblast sonicates*

\begin{tabular}{|c|c|c|c|}
\hline & Patient (E.B.) & Controls & \\
\hline & \multicolumn{2}{|c|}{$\mathrm{nmol} / \mathrm{min} / \mathrm{mg}$ protein } & \\
\hline Pyruvate dehydrogenase (native) & $0.093 \pm 0.014(13)$ & $0.390 \pm 0.033(13)$ & \\
\hline \multirow{2}{*}{ Pyruvate dehydrogenase $\left(\mathrm{Ca}^{++}\right.$activated $)$} & $0.148 \pm 0.034(13)$ & $0.454 \pm 0.054$ & \\
\hline & \multicolumn{2}{|c|}{$\mathrm{nmol} / 30 \mathrm{~min} / \mathrm{mg}$} & \\
\hline \multirow[t]{2}{*}{ Pyruvate decarboxylase $E_{1}$} & $0.470 \pm 0.153(7)$ & $1.41 \pm 0.318(7)$ & \\
\hline & \multicolumn{2}{|c|}{$\mathrm{mmol} / \mathrm{min} / \mathrm{mg}$} & \\
\hline Dihydrolipoyl transacetylase $\mathrm{E}_{2}$ & $13.35 \pm 1.80(4)$ & $19.04 \pm 3.21(4)$ & \\
\hline Lipoamide dehydrogenase $\mathrm{E}_{3}(\mathrm{NADH} \rightarrow \mathrm{NAD})$ & $6.87 \pm 1.16(9)$ & $10.9 \pm 1.00(9)$ & \\
\hline 2-Oxoglutarate dehydrogenase & $0.260 \pm 0.080(6)$ & $0.886 \pm 0.094(6)$ & : \\
\hline 2-Ketoisocaproate dehydrogenase & $0.018 \pm 0.010(3)$ & $0.190 \pm 0.021$ & \\
\hline Pyruvate carboxylase & $1.12 \pm 0.16(4)$ & $1.20 \pm 0.12(4)$ & \\
\hline Phosphoenolpyruvate carboxykinase & $0.790 \pm 0.025(3)$ & $1.32 \pm 0.153(3)$ & \\
\hline
\end{tabular}

* The values are the means \pm SEM and the numbers of observations in parentheses. 
Table 5. Conversion of ${ }^{14} \mathrm{C}$-leucine and ${ }^{14} \mathrm{C}$-valine to ${ }^{14} \mathrm{CO}_{2}$ and organic acids*

\begin{tabular}{|c|c|c|c|}
\hline \multirow{2}{*}{\multicolumn{2}{|c|}{$\begin{array}{l}\text { Leucine } \\
-1-{ }^{14} \mathrm{C}\end{array}$}} & \multicolumn{2}{|r|}{ Valine } \\
\hline & & $-1-{ }^{14} \mathrm{C}$ & $-U_{-}{ }^{14} \mathrm{C}$ \\
\hline & ${ }^{14} \mathrm{CO}_{2}$ & ${ }^{14} \mathrm{CO}_{2}$ & ${ }^{14} \mathrm{C}$-3-OH-isobutyrate \\
\hline & \multicolumn{3}{|c|}{$\mathrm{nmol} / 2 \times 10^{6} \mathrm{cells} / 90 \mathrm{~min}$} \\
\hline Control & 2.80 & 3.22 & 3.96 \\
\hline E.B. & 0.16 & 0.16 & 0.10 \\
\hline E.B. + lipoic & 1.27 & 0.80 & 2.20 \\
\hline T.K. & 0.80 & 0.93 & \\
\hline T.K. + lipoic & 0.62 & 0.80 & \\
\hline
\end{tabular}

* The data represent the means of duplicate incubations and determinations of isotope content in $\mathrm{CO}_{2}$. Duplicates differed from the mean by $11-13 \%$. The 3-hydroxyisobutyrate data represented the sum of fractions collected from a single column. T.K. was a patient with $E_{3}$ deficiency $(3,9)$.

of leucine and valine was unaffected by growing cells of a patient (TK) with $\mathrm{E}_{3}$ deficiency in lipoic acid.

\section{DISCUSSION}

The clinical presentation was unusual in the rather late infantile onset of what clearly was a fatal disease. The patient was not normal from birth, but he was well enough to avoid acute illness and admission to hospital until he was 7 mo of age. Once signs of serious illness began, it proved impossible to consider release from hospital. With time and progressive worsening of illness it became difficult to manage him outside an intensive care unit. Increasing requirements for water and sodium bicarbonate exceeded intestinal tolerance and he required continuous parenteral fluid therapy. He became sufficiently intolerant of protein, fat, and carbohydrate that it became impossible to provide enough nutrients to permit growth. Protein and lipid led to ketoacidosis. Carbohydrate led to increasing lactic acidemia. One can speculate that a late-appearing enzyme defect could reflect the existence of distinct fetal and mature forms of a relevant enzyme, in accordance with the model provided by $\mathrm{Hb} \mathrm{F}$ and $\mathrm{Hb} \mathrm{S}$. Thus an infant might have little or no symptoms when the normally active fetal enzyme predominated, and the later appearance of the mature but defective enzyme would result in clinical illness. An alternative mechanism might be an early dependence on glycolysis, with later transition to oxidative metabolism, but it is difficult to see how this could last 6 mo.

The clinical effectiveness of lipoic acid was difficult to evaluate because of the progressively increasing severity of clinical illness, particularly the renal tubular acidosis. Nevertheless, it did appear to be of clinical benefit in this disorder. Its administration was followed by a cessation in ketonuria occurring in the presence of oral amounts of protein and lipid that were incompatible with growth. In the presence of lipoic acid it was possible to double the intake of protein and lipid without the return of ketonuria or 3-hydroxybutyric aciduria. Moreover, the quantities of lactate in the urine decreased despite increased intake of carbohydrate.

The effects of the in vitro addition of lipoic acid to the culture media were substantial improvements in the ability of E.B. cells to oxidize leucine and valine, and to convert valine to its major metabolic product 3-hydroxyisobutyric acid. They were also consistent with our interpretation of the data on enzyme activity that $\mathrm{E}_{3}$ was normal. There was no in vitro response to lipoic acid in the patient T.K. (12) with $E_{3}$ deficiency, and this would appear intuitively to be consistent because the $E_{3}$ enzyme is responsible simply for the reduction of lipoic acid already covalently bound to the $\mathrm{E}_{2}$ complex. It would be difficult to understand how added lipoic acid would affect that process. However, a favorable clinical response to lipoic acid has been reported in a patient with $\mathrm{E}_{3}$ deficiency (6).
The metabolic response to what was clearly a toxic dose of lipoic acid was of interest. The diuresis and acidosis could have reflected the accumulation and excretion of lipoic acid itself after a dose that amounted to $150 \mathrm{mg} / \mathrm{kg}$. The excretion of 2-oxoglutarate, fumarate, and malate decreased, suggesting an effect on ketoglutarate dehydrogenase. The impressive hyperglycemia that occurred, and the equally impressive hypoglycemia when it was stopped, argue for an effect of lipoic acid on carbohydrate metabolism. This would appear to be other than an effect on pyruvate dehydrogenase that would be expected to improve the oxidative metabolism of carbohydrate.

The renal tubular acidosis was a major contributor to problems of management. The defect in renal tubular function could be a consequence of an adverse effect of accumulated organic acids. We have reported the occurrence of renal tubular acidosis and bicarbonate wasting in methylamonic acidemia (13). Renal tubular acidosis has been produced in experimental animals by the administration of maleic acid (14). This raises the possibility that it was disruption of the citric acid cycle in this patient rather than accumulated acid that was responsible for the renal tubular acidosis. We have also observed renal tubular acidosis in a patient with cytochrome oxidase deficiency. It is possible that renal tubular function is particularly sensitive to the malfunction of oxidative metabolism.

The study of enzyme activities in fibroblast sonicates indicated clearly that there was effective deficiency of PDHC and the 2ketoglutarate dehydrogenase. Similarly the branched-chain keto acid dehydrogenase was deficient. The oxidation by cultured fibroblasts of $1-{ }^{14} \mathrm{C}$-leucine and $1-{ }^{14} \mathrm{C}$-valine to ${ }^{14} \mathrm{CO}_{2}$ was also demonstrably deficient. These observations were consistent with the clinical picture of lactic acidemia, worsened by carbohydrate and ketoacidotic intolerance to protein and lipid, as well as the pattern of organic acids in the urine. The data are all consistent with what has been reported in $\mathrm{E}_{3}$ deficiency $(4-6,12,15-17)$. However, the activity of $E_{3}$ as measured in fibroblast sonicates appeared to be normal. Certainly it was not appreciably different from those of $E_{2}$ or phosphoenolpyruvate carboxykinase. In contrast a patient with documented complete deficiency of $E_{3}$ in liver and muscle (4) had 5\% of control activity in the same assay in fibroblasts. This patient also had an absent histochemical reaction to $E_{3}$, whereas that of E.B. appeared normal. Immunoprecipitation of $E_{3}$ revealed that the enzyme protein in E.B. was present in amounts similar to that found in control cell lines and that the mol wt was also the same (16).

In the presence of deficient activity of the branched-chain keto acid dehydrogenase, it is of interest that the concentrations of the branched-chain amino acids were not increased as they are in maple syrup urine disease. This suggests that the affinity of whatever the central factor is for the branched-chain keto acid dehydrogenase is greater than those for pyruvate and 2-oxoglutarate dehydrogenase. It is consistent with what has been encountered in $\mathrm{E}_{3}$ deficiency in which elevated levels of alanine are regularly encountered $(4,15)$, in contrast to maple syrup urine disease where they are depressed, and levels of leucine, isoleucine, and valine were normal or only slightly elevated $(5,7,12,15$, 18).

We have speculated from the effects of lipoic acid that the molecular basis of disease in this patient might be in an enzyme not yet described that is responsible for the attachment of lipoic acid to $E_{2}$. An analogy would be the enzyme holocarboxylase synthetase that catalyzes the attachment of biotin to apocarboxylase enzymes and represents the molecular cause of the neonatal form of multiple carboxylase deficiency (19). The biochemical phenotype one might expect from defective attachment of lipoic acid would include defective activities of branched-chain keto acid dehydrogenase as well as pyruvate and 2-oxoglutarate dehydrogenase; growth of fibroblasts in medium rich in lipoic acid might return these activities toward normal. This would be consistent with the functional improvement observed in the metabolism of both leucine and valine. 


\section{REFERENCES}

1. Nyhan WL and Sakati, NO 1987 Diagnostic Recognition of Genetic Disease. Lea \& Febiger, Philadelphia, pp 221-237

2. Kuroda Y, Kline JJ, Sweetman L, Nyhan WL, Groshong TD 1979 Abnorma pyruvate and $\alpha$-ketoglutarate dehydrogenase complexes in a patient with lactic acidemia. Pediatr Res 12:928-931

3. Kuhara T, Shinka T, Inoue Y, Matsumoto M, Yoshino M, Sakaguchi Y, Matsumoto I 1983 Studies of urinary organic acid profiles of a patient with dihydrolipoyl dehydrogenase deficiency. Clin Chim Acta 133:133-140

4. Robinson BH, Taylor J, Kahler SG, Kirkman HN 1981 Lactic acidemia neurologic deterioration and carbohydrate dependence in a girl with dihydrolipoyl dehydrogenase deficiency. Eur J Pediatr 136:35-39

5. Robinson BH, Taylor J, Sherwood WG 1977 Deficiency of dihydrolipoyl dehydrogenase (a component of pyruvate and $\alpha$-ketoglutarate dehydrogenase complexes): a cause of congenital lactic acidosis in infancy. Pediatr Res 11:1198-1202

6. Matalon R, Stumpf DA, Michals K, Hart RD, Park JK, Goodman SI 1984 Lipoamide dehydrogenase deficiency with primary lactic acidosis: favorable response treatment with oral lipoic acid. J Pediatr 104:65-69

7. Matalon R, Michals K, Stumpf D., Goodman S, Parks J 1981 Lactic acidosis due to lipoamide dehydrogenase (LAD) deficiency: improvement after oral lipoic acid. Am J Hum Genet 33:48A

8. Spackman DA, Stein WH, Moore S 1958 Automatic recording apparatus for use in the chromatography of amino acids. Anal Chem 30:1 190-1206

9. Sweetman L 1974 Liquid partition chromatography-mass spectrometry in identification of acid metabolites of amino acids. In: Nyhan WL (ed) Heritable Disorders of Amino Acid Metabolism. Wiley, New York, pp 730751

10. Yoshida I, Sweetman L, Nyhan WL 1986 Metabolism of branched-chain amino acids in fibroblasts from patients with maple syrup urine disease and other abnormalities of branched-chain ketoacid dehydrogenase activity. Pe- diatr Res 20:169-174

11. Taylor SI, Nukherjee C, Jungas RL 1973 Studies on the mechanism of activation of adipose tissue pyruvate dehydrogenase by insulin. J Biol Chem 248:73-81

12. Matuda S, Kitano S, Sakaguchi Y, Yoshino M, Saheki T 1984 Pyruvate dehydrogenase subcomplex with lipoamide dehydrogenase deficiency in a patient with lactic acidosis and branched-chain ketoaciduria. Clin Chim Acta 140:59-64

13. Wolff JA, Strom C, Griswold W, Sweetman F, Kulovich S, Prodanos C, Nyhan WL 1985 Proximal renal tubular acidosis in methylmalonic acidemia. J Neurogenet 2:31-39

14. Harrison HE, Harrison HC 1954 Experimental production of renal glycosuria, phosphaturia, and aminoaciduria by injection of maleic acid. Science 120:606-608

15. Munnich A, Saudubray JM, Taylor J, Charpentier C, Marsac C, Rocchiccioli F, Amedee-Manesame O, Coude FX, Frezal J, Robinson BH 1982 Congenital lactic acidosis, $\alpha$-ketoglutaric aciduria and variant form of maple syrup urine disease due to a single enzyme defect. Dihydrolipoyl dehydrogenase deficiency. Acta Pediatr Scand 71:167-171

16. Otulakowski G, Nyhan W, Sweetman L, Robinson BH 1985 Immunoextraction of lipoamide dehydrogenase from cultured skin fibroblasts in patients with combined $\alpha$-ketoacid dehydrogenase deficiency. Clin Chim Acta 152:27-36

17. Taylor J, Robinson BH, Sherwood WG 1978 A defect in branched-chain amino acid metabolism in a patient with congenital lactic acidosis due to dihydrolipoyl dehydrogenase deficiency. Pediatr Res 12:60-62

18. Sakaguchi Y, Yoshino M, Aramaki S, Yoshida I, Yamashita FA, Kuhara T, Matsumoto I, Hayashi T 1986 Dihydrolipoyl dehydrogenase deficiency: a therapeutic trial with branched-chain amino acid restriction. Eur J Pediatr $145: 271-274$

19. Burri BJ, Sweetman L, Nyhan WL 1985 Heterogeneity of holocarboxylase synthetase in patients with biotin-responsive multiple carboxylase deficiency. Am J Hum Genet 37:326-337 